\title{
11. OLIGOCENE DEEP-WATER AGGLUTINATED FORAMINIFERS AT SITE 985, NORWEGIAN BASIN, SOUTHERN NORWEGIAN SEA ${ }^{1}$
}

\author{
Michael A. Kaminski² and William E.N. Austin ${ }^{3}$
}

\begin{abstract}
The stratigraphic distribution of deep-water agglutinated foraminifers was examined using 50 samples from Ocean Drilling Program (ODP) Hole 985A, drilled on the gentle slope of the Iceland Plateau in the Norwegian Basin. A total of 40 species and generic groupings was determined in this study. Three stratigraphically meaningful assemblages are recognized in Hole 985A: a basal assemblage with coarsely agglutinated forms (Cores 162-985A-62X through 50X), a Spirosigmoilinella compressa assemblage (Cores 162-985A-49X through 40X), and a sparse assemblage with pyritized radiolarians in the uppermost part of the studied interval (Cores 162-985A-39X through 32X). The whole succession from the base of Hole 985A to Core 162-985A$32 \mathrm{X}$ is here assigned to the Dorothia siegliei-Rotaliatina bulimoides Zone of Oligocene age. The stratigraphic ranges of several species extended into younger strata compared with biostratigraphic records from the Vøring Slope (ODP Hole 643A) and from an exploration well on the Vøring Plateau.

Taxonomic differences between the foraminiferal records of the Norwegian Sea and the deep Labrador Sea provide evidence for faunal isolation of the deep Norwegian basin during the Oligocene. This isolation is attributed to limited marine connections across the Greenland-Scotland Ridge, resulting in Norwegian Sea deep water that was corrosive and poorly ventilated. Foraminiferal evidence suggests that Norwegian Sea deep water was poorly oxygenated during the Oligocene.
\end{abstract}

\section{INTRODUCTION}

Deep-water agglutinated foraminifers (DWAF) have been used in biostratigraphic correlation in the North Sea and Norwegian Sea since the 1970s. The first round of deep-sea drilling (Leg 38) revealed that the Paleogene sediments recovered from the Norwegian Sea contain a fairly continuous record of microfossil assemblages composed almost exclusively of DWAF (Talwani, Udintsev et al., 1976). In nearly all the Deep Sea Drilling Project (DSDP)/Ocean Drilling Program (ODP) holes from the Norwegian Sea region, Paleogene calcareous benthic foraminifers are either completely lacking or have been found only in discrete horizons at comparatively shallow sites on the Vøring Plateau (Hulsbos et al., 1989). In their synthesis of the Paleogene material from Leg 38 sites, Verdenius and van Hinte (1983) succeeded in subdividing the Paleogene record into a number of assemblage zones that were useful for local stratigraphic correlation.

During the early 1980s, several biostratigraphic schemes based on agglutinated foraminifers were devised for the Paleogene of the North Sea region (Gradstein and Berggren, 1981; King, 1983; Gradstein et al., 1988). It became apparent that a number of EoceneOligocene DWAF species occur throughout the North Sea, Norwegian Sea, and Labrador Sea, suggesting that they may be useful for correlation purposes throughout the northern part of the North Atlantic. Subsequent studies have further refined the taxonomy and biostratigraphy of Norwegian Sea DWAF (Gradstein and Kaminski, 1989; Kaminski et al., 1990; Osterman and Spiegler, 1996; Kaminski and Geroch, 1997; Nagy et al., in press; Gradstein and Kaminski, 1997). Quantitative studies of biostratigraphic data from 33 North Sea and Norwegian Sea exploration wells have yielded a refined biostratigraphic zonation of the area using DWAF and other microfossils (Gradstein et al., 1988; Gradstein et al., 1992, 1994; Gradstein and Bäckström, 1996).

${ }^{1}$ Raymo, M.E., Jansen, E., Blum, P., and Herbert, T.D. (Eds.), 1999. Proc. ODP, Sci. Results, 162: College Station, TX (Ocean Drilling Program).

${ }^{2}$ Research School of Geological and Geophysical Sciences, University College London, Gower Street, London WC1E 6BT, United Kingdom.

${ }^{3}$ Environmental Research Centre, Department of Geography, University of Durham, South Road, Durham DH1 3LE, United Kingdom. bill.austin@durham.ac.uk
Initial shipboard investigations revealed that a thick sequence of Oligocene sediments containing rich DWAF assemblages, but few other microfossil remains, was recovered from Hole 985A. Our primary purpose in studying this material was to refine the biostratigraphy of the Oligocene/Miocene transition in the Norwegian Sea at a site that appears to contain a much-expanded Oligocene section. Because of its location in the central part of the Norwegian Sea, we expected Hole $985 \mathrm{~A}$ to contain a more continuous Oligocene record than at Site 643 on the Vøring Slope or elsewhere on the Vøring Plateau, an area where sedimentation may have been influenced by oceanic currents. The Oligocene at Site 643 is considerably thinner than at Site 985, and one or more hiatuses may be present at Site 643 (Kaminski et al., 1990). Additionally, our second purpose for studying the DWAF was to undertake detailed observations of the morphology and wall structure of selected species that were first described from the North Sea region (M.A. Kaminski and W.E.N. Austin, unpubl. data). Because of the thick overburden in the North Sea region, Oligocene forms are typically silicified and compressed. At Site 985, on the other hand, the Neogene sediments are relatively thin; as a result, the DWAF display excellent preservation.

At present the chronostratigraphic control at Site 985 remains poor because of the lack of calcareous microfossils that would enable correlation with the standard planktonic zonal schemes. The sequence was dated by means of magnetic polarity records to the latest Miocene; below this, it was difficult to correlate with the geomagnetic polarity time scale (Shipboard Scientific Party, 1996). Thus, the underlying sequence has poor age constraints. We hope that future palynological studies from this hole may enable a better correlation with the standard zonal schemes. The poor independent age control means that chronostratigraphic assignments are based solely on agglutinated foraminifers. We achieved this by correlating our biostratigraphic sequence with the Oligocene benthic foraminiferal zonations developed for the Norwegian and North Sea regions.

\section{BACKGROUND}

Site 985 is located on Eocene Anomaly 22 crust ( 50 Ma; Talwani and Eldholm, 1977). Geological evidence supports the notion of seafloor spreading in the Norwegian-Greenland Sea by Anomaly 24 
(early Eocene), but crustal extension may have begun as early as Anomaly 29 (Talwani and Eldholm, 1977; Myhre and Thiede, 1995).

Site 985 was drilled on the gentle slope of the Iceland Plateau at a water depth of $2788 \mathrm{~m}$ at $66^{\circ} 56.49^{\prime} \mathrm{N}, 6^{\circ} 27.01^{\prime} \mathrm{W}$ (Fig. 1). It is part of the paleoenvironmental transect of the southern part of the Norwegian Sea and is composed of Sites 907 and 987 (Legs 151 and 162, respectively) and Sites 642, 643, and 644 (Leg 104). The sediments recovered are predominantly fine-grained siliciclastics. The dominant lithologies include silty clays, clays with silt, and clays. Biocarbonates are restricted to the upper parts of the sedimentary sequence. Clays and silty clays containing biosilica are encountered only between 240 and 290 meters below seafloor (mbsf). Disseminated volcanic ash, ash pods, and ash layers occur throughout the sedimentary sequence. Dropstones are confined to the upper sedimentary sequence (0-70 mbsf). The upper part of the sequence (1-60 mbsf) was dated to the latest Miocene by means of magnetic polarity records, but the underlying sequence proved difficult to correlate with the geomagnetic polarity time scale. Thus, it has poor age constraints. Siliceous microfossils and agglutinated benthic foraminifers provide some age information in the lower section, indicating that the drilled sequence terminated in the Oligocene.

Five lithologic units were recognized in Hole 985A, and the agglutinated assemblages described here appear within the lowermost part of Unit IV (155.2 to $465 \mathrm{mbsf}$ ) and Unit V (465 to $578.9 \mathrm{mbsf}$ ). The sediments of Unit IV are dominated by indurated clays, ranging from gray to very dark greenish gray to dark grayish brown. Disseminated ash is present as a lithologic component of the bulk sediments. The relevant subunit of Unit IV is defined from 289.6 to $465 \mathrm{mbsf}$ and is characterized by the absence of biosilica and the gradual downsection increase in natural gamma counts. The base of Subunit IVC is defined by a sharp downhole increase in magnetic susceptibility. The sediments of Unit V comprise indurated dark greenish gray to very dark greenish gray clay, olive gray to dark greenish gray clay, and very dark greenish gray clay with glauconite and glauconitic clay. These sediments are distinguished from the overlying sediments by a sharp increase in magnetic susceptibility.

The lowermost sediments (Unit V) are believed to have been deposited during the late Oligocene to early Miocene when the basin was roughly half its modern dimensions; Site 985 was, therefore, shallower and closer to land. At this time, the Aegir spreading axis, the site of active seafloor spreading, was located to the east of Site 985. The lack of an intervening bathymetric high between Greenland and Site 985 may have permitted more effective transport of silt-sized terrigenous material to Site 985.

\section{METHODS}

Standard methods of sample processing were applied to $20-\mathrm{cm}^{3}$ plugs removed from split-core sections. These were dried at $40^{\circ} \mathrm{C}$ to constant weight and then soaked in tepid distilled water for up to 24 $\mathrm{hr}$ before wet sediment sieving on a $63-\mu \mathrm{m}$ mesh. Sediment disaggregation was variable, but most samples broke down readily after gentle sieving with warm tap water. Coarse residues were retained and dried at $40^{\circ} \mathrm{C}$ to constant weight. Foraminifers were picked from the entire $>63-\mu \mathrm{m}$ residue. Specimens were photographed using a Zeiss
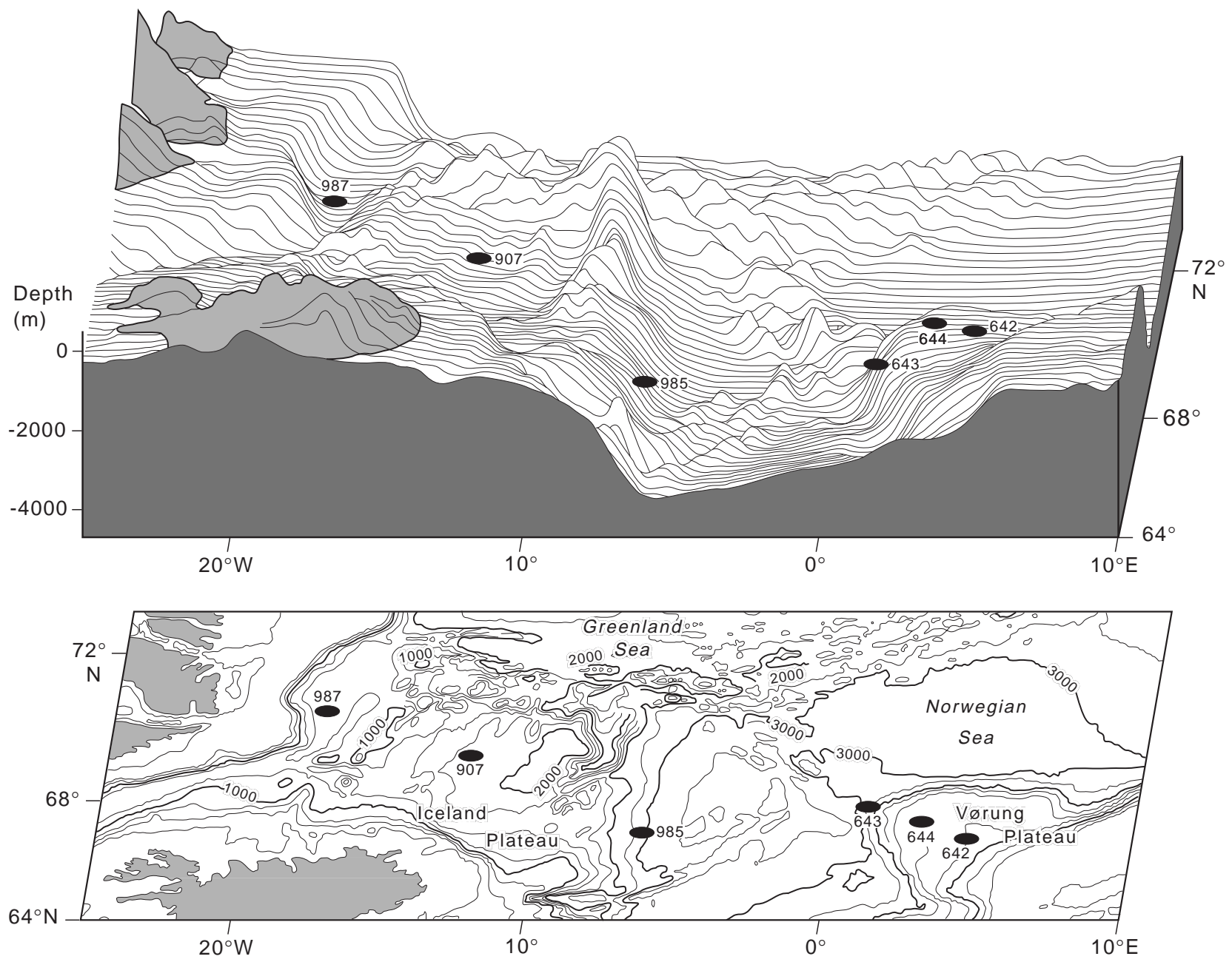

Figure 1. Map view of Site 985, with locations of other North Atlantic DSDP/ODP sites where DWAF have been studied. 
940 digital scanning electron microscope at University College London.

\section{RESULTS}

Examination of the 49 samples from Core 162-985A-32X to the base of the hole (Section 162-985A-62X-CC) yielded 40 foraminiferal species and generic groupings (Table 1). Specimens throughout the studied interval are generally well preserved and uncrushed. The succession of foraminiferal assemblages, the ranges of some characteristic species, and a simple measure of species diversity observed in sediment from the hole are given in Figure 2.

Based on the ranges of characteristic species, we can subdivide the succession into three main assemblages. Because of the current lack of independent age control, we have refrained from establishing a formal zonation based on this site. Instead, we compare our stratigraphic record with the Paleogene assemblages described from Hole 643A (Kaminski et al., 1990) and from a well drilled on the Vøring Plateau (Gradstein et al., 1994), and with the quantitative zonation based on ranking and scaling of the Norwegian margin (Gradstein and Bäckström, 1996). The three assemblages are described in order from oldest to youngest.

\section{Coarsely Agglutinated Assemblage (Cores 162-985A-62X through 50X)}

The DWAF assemblage in the lower part of the studied section is characterized by coarsely agglutinated species such as Hyperammina rugosa Verdenius and van Hinte, Rhabdammina spp., Psammosphaera fusca Schultze, and numerous Ammolagena clavata (Jones and Parker) that are attached to large quartz grains. This indicates the availability of plentiful coarse material for the construction of the foraminiferal test. Other common species include Reticulophragmium amplectens (Grzybowski), Haplophragmoides walteri (Grzybowski), Reophax elongatus Grzybowski, and Recurvoides spp. A number of stratigraphically important forms are also present.

The lowermost sample collected from Hole 985A (Sample 162985A-62X-CC) contains the index species Spirosigmoilinella compressa (Matsunaga), Adercotryma agterbergi Gradstein and Kaminski, and Karreriella siegliei (Gradstein and Kaminski). These species are characteristic of the lower Oligocene recovered from exploration wells on the Vøring Plateau (Gradstein et al., 1994). An early Oligocene age for the base of the drilled section is corroborated by the absence of Eocene index forms such as Spiroplectammina spectabilis (Grzybowski) and Ammomarginulina aubertae Gradstein and Kaminski.

The first occurrence (FO) of the species Reticulophragmium rotundidorsatum (Hantken) was found in Sample 162-985A-59X-CC; in the next sample above $(59 \mathrm{X}-4,32-37 \mathrm{~cm})$, it is especially common. This species is present in large numbers at certain horizons. The FO of the species Psamminopelta gradsteini Kaminski and Geroch [ = Psamminopelta sp. of Kaminski et al., 1990] was observed in Sample 162-985A-53X-7, 36-0 cm. This occurrence implies a correlation with the Oligocene "Psamminopelta sp. assemblage" observed in the Oligocene sediments at Site 643 on the Vøring Slope (Kaminski et al., 1990).

\section{Spirosigmoilinella Compressa Assemblage (Cores 162-985A-49X through 40X)}

A faunal change is observed within Core 162-985A-50X characterized by the loss of coarsely agglutinated forms. The last occurrence (LO) of the coarsely agglutinated species Hyperammina rugosa was observed in Sample 162-985A-50X-7, 36-40 cm. In Sample 162-985A-50X-CC, the LO of Psammosphaera fusca was observed. Above Core 162-985A-50X, the DWAF assemblage is dominated by finely agglutinated taxa. The characteristic species in this interval are
Bathysiphon spp., Spirosigmoilinella compressa, Verneuilinoides sp., Cystammina sp., Karreriella siegliei, and Ammodiscus latus Grzybowski.

The diversity and abundance of DWAF decrease upsection in Hole 985A. A reduction in diversity is observed within the interval from Cores 162-985A-45X through 43X. The LOs of 12 species are observed within this interval, including Reophax elongatus, Adercotryma agterbergi, Reticulophragmium rotundidorsatum, Ammodiscus latus, and Haplophragmoides walteri. Many of these last occurrences can be traced to a level within the Oligocene in the North Sea region (Gradstein et al., 1994).

\section{Sparse Assemblage with Pyritized Radiolarians (Cores 162-985A-39X through 32X)}

In the uppermost part of the studied interval, the assemblages contain common pyritized diatom and radiolarian steinkerns. Some authigenic pyrite, in the form of burrow infillings, was also observed. Foraminifers are rare and consist mainly of Psamminopelta gradsteini in association with rare tubular forms and Recurvoides spp. These findings agree with the observations of Verdenius and van Hinte (1983) in the Leg 38 DSDP holes (Sites 338, 345, and 348), where low-diversity assemblages with "Spirosigmoilinella and Spirolocammina" were reported from strata assigned a late Oligocene to Miocene age.

\section{DISCUSSION}

\section{Stratigraphic Significance of the Taxa Recovered at Site 985}

The base of the recovered sedimentary section in Hole 985A (Sample 162-985A-62X-CC) contains several stratigraphically important forms. Spirosigmoilinella compressa (Matsunaga) was originally described from the Miocene of Japan. Its FO in the North Atlantic region was calibrated to the standard nannofossil zonation at Site 647 in the Labrador Sea (Kaminski et al., 1989). In this area, its FO lies within the upper Eocene (nannofossil Zone NP17). In the North Sea exploration wells, its FO usually marks the base of the Oligocene sedimentary sequences. In the North Sea area, however, the Eocene/Oligocene boundary is represented by a hiatus, and much of the upper Eocene is generally missing. At Site 643 on the Vøring Slope, its FO was observed in Sample 162-643A-49X-5, 79-84 cm. Based on this correlation, we can assume that the base of the recovered sediments at Site 985 is no older than early Oligocene. S. compressa was reported to range into the upper Miocene in Hole 909C in the Fram Strait (Osterman and Spiegler, 1996). However, in their study of the Leg 151 material, Osterman and Spiegler did not separate this species from Psamminopelta gradsteini.

At Labrador Sea Site 647, the LO of Reticulophragmium amplectens was observed at the Eocene/Oligocene boundary as determined by nannofossil and magnetostratigraphy. This species, however, ranges into the Oligocene in the Norwegian Sea at Site 643 (Kaminski et al., 1990) and in the Canadian Arctic (Schröder-Adams and McNeil, 1994). Our observations at Site 985 confirm its overlap with $S$. compressa and its continued range into younger sediments north of the Greenland-Scotland Ridge. In the northern part of the Norwegian Sea at Site 909, it was reported to range into the middle Miocene (Osterman and Spiegler, 1996).

In Core 162-985A-59X, an assemblage with common specimens of Reticulophragmium rotundidorsatum is observed. This species was originally described from the middle Oligocene Kiscell Marls of Hungary (Hantken, 1875). However, the specimens at this level are much smaller than the types preserved at the Natural History $\mathrm{Mu}$ seum in Vienna. They are more similar, both in size and shape, to late Eocene specimens from the Carpathian Flysch deposits where an upper Eocene $R$. rotundidorsatum Zone has been recognized (Geroch and Nowak, 1984). This would imply that the base of the recovered 
Table 1. Foraminiferal abundance data from studied samples, Hole 985A, Norwegian Sea.

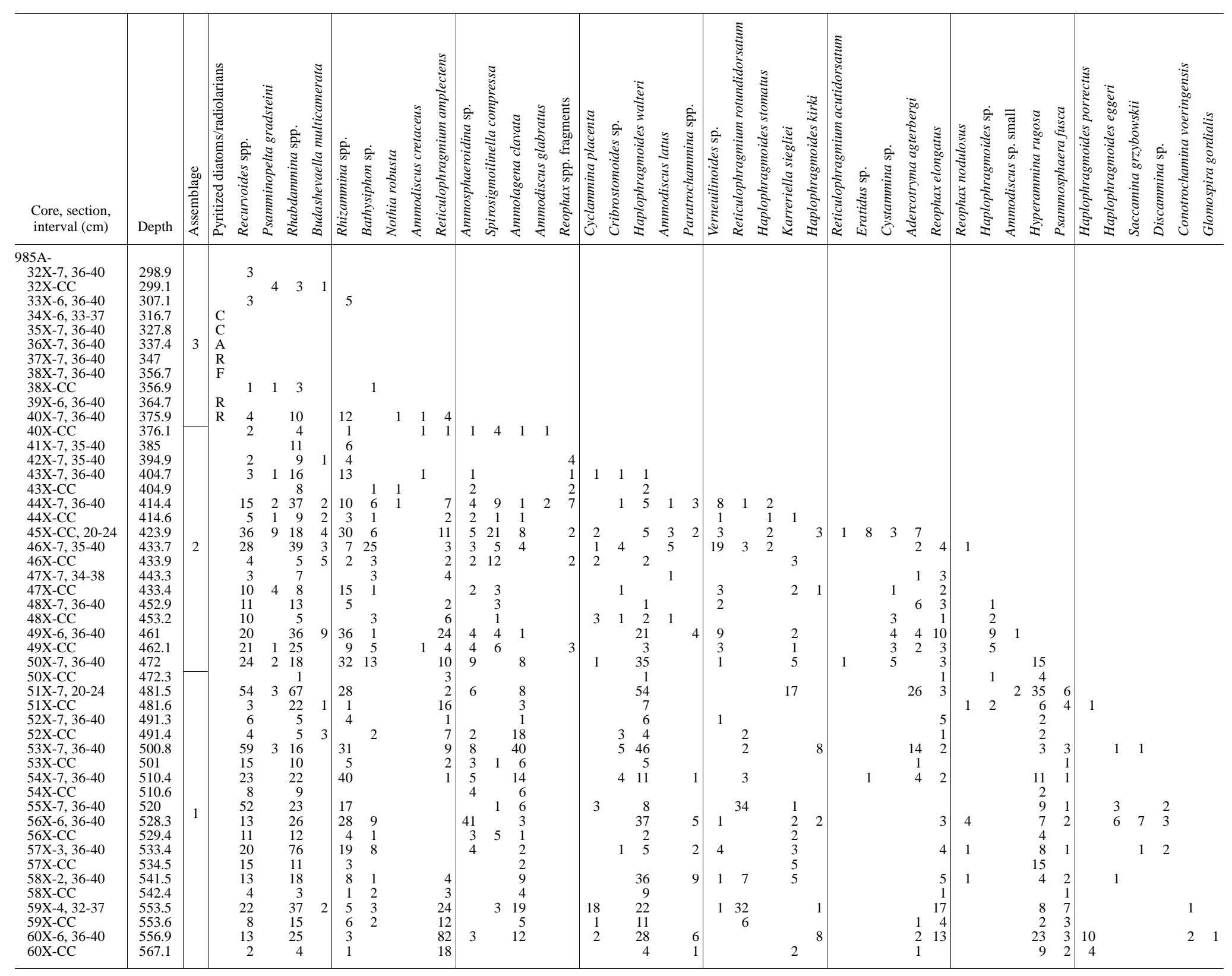


section is older than the mid-Oligocene. Larger specimens of $R$. rotundidorsatum are observed higher in the section, in Sample 162985A-46X-7. The occurrence of these ancestral forms at the base of Hole 985A implies that the sediments are older than the "Kiscellian" of Hungary. $R$. rotundidorsatum is a cosmopolitan form that ranges into the middle to upper Miocene, occurring also in the Oligocene to upper Miocene in the Beaufort-MacKenzie Basin (Schröder-Adams and McNeil, 1994) and in the Miocene "Agua Salada Fauna" in the Gulf of Mexico (M.A. Kaminski, unpubl. data). In the northern Norwegian Sea, Osterman and Spiegler (1996) reported an R. rotundidorsatum assemblage of late Miocene age in Hole 909C.

Karreriella siegliei, observed at the base of Hole 985A, is the nominate taxon of the early Oligocene Dorothia siegliei Zone of Gradstein et al. (1994) in the North Sea. At Site 643, its FO was ob-

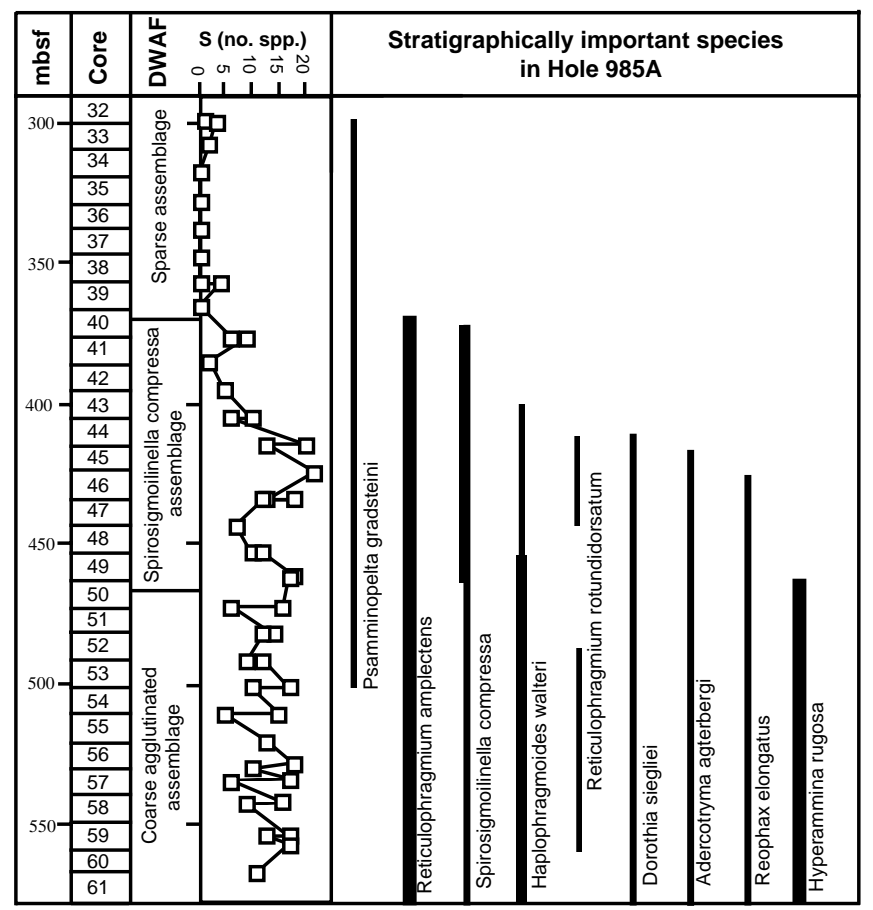

Figure 2. Ranges of stratigraphic index taxa in Hole 985A. Diversity is given as $\mathrm{S}$ (the number of species in each sample). served in Core 162-643A-47X, which was assigned an Oligocene age (Kaminski et al., 1990). Its LO was reported within the upper Miocene $R$. rotundidorsatum assemblage at Site 909 (Osterman and Spiegler, 1996).

At DSDP Sites 338, 346, 349, and 350, Verdenius and van Hinte (1983) found the distinctive species Spiroplectammina spectabilis in sediments of Eocene age. At the Labrador Sea Site 647, the LO of this species coincided with the Eocene/Oligocene boundary (Kaminski et al., 1989). Based on the occurrence of the above-mentioned species and the lack of $S$. spectabilis in our samples, we conclude that the base of the recovered sediment column at Site 985 is no older than early Oligocene.

\section{Comparison with Biostratigraphic Records at Site 643 and Haltenbanken}

To assess the utility of DWAF for stratigraphic correlation in the area of the southern Norwegian Sea, we compiled the LOs of common species in the Eocene-Oligocene at three localities (Fig. 3). M.A. Kaminski has studied all three localities, ensuring consistent taxonomic concepts. Several stratigraphically important species are common to all three locations, including $S$. compressa, $R$. elongatus, $H$. walteri, Cyclammina placenta, R. amplectens, and D. seigliei. This comparison of the LOs also reveals information about the paleoecological preferences of the species.

There is relatively good agreement between the sequence of LOs in the two ODP records from the deep Norwegian Sea (Fig. 3). In both ODP holes, the "coarse agglutinated species" (i.e., Recurvoides, Cribrostomoides, and Rhabdammina) and Psamminopelta gradsteini are among the last of the Oligocene forms to disappear. Within the Oligocene sediments, the species Ammosphaeroidina pseudopauciloculata, C. placenta, H. walteri, Haplophragmoides kirki, and $H$. rugosa display a consistent sequence of last occurrences. This relatively good correlation between the FOs in Holes 985A and 643A suggests that similar ecological controls on DWAF may have been present at both localities. Deep-water masses in the Norwegian Sea were undersaturated with respect to carbonate, and DWAF persisted well into the Oligocene in the deeper parts of the basin. At Site 909 situated in the Fram Strait, a diverse DWAF assemblage was recovered in sediments of middle to late Miocene age (Osterman and Spiegler, 1996), indicating that favorable ecological conditions persisted much later at the high latitudes. There are some inexplicable differences between the foraminiferal records at Sites 985 and 643. For example, $R$. rotundidorsatum was not found at Site 643, and C. voerin-

\begin{tabular}{|c|c|c|}
\hline $\begin{array}{l}\text { Last Occurrences } \\
\text { in Hole } 985 \mathrm{~A}\end{array}$ & $\begin{array}{l}\text { Last Occurrences } \\
\text { in Hole 643A }\end{array}$ & $\begin{array}{l}\text { Last Occurrences } \\
\text { Norwegian Margin }\end{array}$ \\
\hline $\begin{array}{l}\text { Coarse agglutinated species } \\
\text { Psamminopelta gradsteini } \\
\text { Budashevaella multicamerata } \\
\text { Reticulophragmium amplectens } \\
\text { A. pseudopauciloculata } \\
\text { Spirosigmoilina compressa } \\
\text { Ammolagena clavata } \\
\text { Cyclammina placenta } \\
\text { Haplophragmoides walteri } \\
\text { Ammodiscus latus } \\
\text { Reticulophragmium rotundidorsa } \\
\text { Karreriella siegliei } \\
\text { Haplophragmoides kirki } \\
\text { Reticulophragmium acutidorsatu } \\
\text { Adercotryma agterbergi } \\
\text { Reophax elongatus } \\
\text { Reophax nodulosus } \\
\text { Hyperammina rugosa } \\
\text { Psammosphaera fusca } \\
\text { Conotrochammina voeringensis } \\
\text { Glomospira gordialis }\end{array}$ & $\begin{array}{l}\text { Coarse agglutinated species } \\
\text {-Spirosigmoilina compressa } \\
\text {-Psamminopelta gradsteini } \\
\text { Reticulophragmium acutidorsatum } \\
\text { A. pseudopauciloculata } \\
\text { Karreriella siegliei } \\
\text { Reticulophragmium amplectens } \\
\text { - Cyclammina placenta } \\
\text { Reophax nodulosus } \\
\text { Ammolagena clavata } \\
\text { Haplophragmoides walteri } \\
\text { Budashevaella multicamerata } \\
\text { Adercotryma agterbergi } \\
\text { Glomospira gordialis } \\
\text { Haplophragmoides kirki } \\
\text { Karrerulina horrida } \\
\text { - Hyperammina rugosa } \\
\text {-Reophax elongatus } \\
\text { Haplophragmoides excavatus } \\
\text { - Conotrochammina voeringensis } \\
\text { Karrerulina conversa }\end{array}$ & $\begin{array}{l}\text { Coarse agglutinated species } \\
\text { Gyroidina girardana } \\
\text { Cyclammina placenta } \\
\text { Spirosigmoilinella compressa } \\
\text { Turrilina alsatica } \\
\text { Aschemonella grandis } \\
\text { Reticulophragmium rotundidorsatum } \\
\text { Rotaliatina buliminoides } \\
\text { Karrerulina horrida } \\
\text { Ammodiscus latus } \\
\text { Annectina biedai } \\
\text { Adercotryma agterbergi } \\
\text { Reophax elongatus } \\
\text { Haplophragmoides walteri } \\
\text { Karreriella siegliei } \\
\text { Globigerapsis index } \\
\text { Recurvoides ex gr. walteri } \\
\text { Reticulophragmium amplectens } \\
\text { A. pseudopauciloculata } \\
\text { Haplophragmoides kirki } \\
\text { Karrerulina conversa }\end{array}$ \\
\hline
\end{tabular}

Figure 3. Comparison of the sequence of last occurrences in Hole 985A, Hole 643A (Vøring Slope), and in quantitative biozonation of the Vøring Plateau and northern North Sea (Norwegian margin) of Gradstein and Bäckström (1996). Taxonomic names are listed in order of their stratigraphic occurrence and have been updated to facilitate comparison. The species given in bold occur at the top of the Eocene succession. 
gensis ranges into the Oligocene at Site 985. It was found only in sediments of the Eocene age at Site 643.

However, along the shallow margins of the Norwegian Sea and in the central North Sea situated toward the south, a change from predominantly agglutinated assemblages to calcareous assemblages is generally observed within the lower Oligocene (Gradstein et al., 1994; Gradstein and Bäckström, 1996). At bathymetrically shallow sites on the Vöring Plateau, the Oligocene sediments contain a benthic assemblage consisting of both calcareous and agglutinated species with Turrilina alsatica and Rotaliatina buliminoides. Some species known from the Haltenbanken area are absent at Sites 985 and 643 (e.g., Annectina biedai Gradstein and Kaminski and Aschemocella grandis [Grzybowski]), whereas others have markedly different stratigraphic ranges. A number of DWAF species that persisted into the Oligocene at the deeper sites display LOs within the Eocene sediments in the quantitative zonation of Gradstein and Bäckström (1996), including $R$. amplectens, A. pseudopauciloculata, and $H$. kirki (Fig. 3). Dorothia siegliei does not range above the Eocene in wells from the Haltenbanken area (Gradstein and Bäckström, 1996), but it does range into the Oligocene sequence in the northern North Sea and in our ODP holes.

Some species display stark differences in their stratigraphic ranges in different areas of the Norwegian Sea. For example, Hyperammina rugosa was first described from the Oligocene of the DSDP Leg 38 sites (Verdenius and van Hinte, 1983). Its LO in the North Sea and western Barents Sea consistently lies within the upper Paleocene. At Site 643, this species was also found in the lower Eocene. Osterman and Spiegler (1996) recorded it from middle to upper Miocene sediments at Site 909.

The diachronous LOs of deep-water species such as Haplophragmoides walteri, Ammosphaeroidina pseudopauciloculata, Reticulophragmium amplectens, and the coarsely agglutinated forms are consistent with a bathymetric shallowing of the Vøring Plateau (owing to infill of the basin and lower Oligocene sea levels). The early Oligocene faunal turnover also reflects changes in surface-water masses in the Norwegian Sea, which allowed the establishment and preservation of calcareous microfossils.

\section{Faunal Connections to the Atlantic}

The role of the Greenland-Scotland Ridge as an effective barrier to the exchange of deep water between the Atlantic and the Arctic throughout the Cenozoic is well known (Thiede and Eldholm, 1983). Today, the Norwegian Sea provides the largest volume of Northern Hemisphere deep water (Worthington, 1976). The Greenland-Scotland Ridge acts as a bathymetric barrier, restricting the flow of Norwegian Sea deep water into the North Atlantic. Similarly, this barrier prevents the northward flow of southern-source deep water into the Norwegian Sea. Berggren and Schnitker (1983) suggested that the Faeroe-Shetland Channel may have been opened by subsidence associated with the Hebridean volcanism and that there may have been an exchange of water across the Greenland-Scotland Ridge during the early Eocene. In the geologic past, this blocking effect of the Greenland-Scotland Ridge must have been even greater, as portions of the ridge have been subsiding since the Eocene. These findings are consistent with our understanding of the paleobiogeography of DWAF, which display some interesting differences across the GreenlandScotland Ridge.

By comparing the faunal composition of assemblages at Site 985 with the assemblages from the Paleogene of the Labrador Sea farther south, we can speculate about the extent of faunal connections across the Greenland-Scotland Ridge. These faunal records are important in understanding the history of deep-water connections across this ridge.

If we contrast the Oligocene DWAF species occurring at either side of the Greenland-Scotland Ridge, we notice some paleobiogeographical differences. We can divide the species occurring at Sites 647 (Labrador Sea), 643, and 985 into three categories (Table 2).

The first species group constitutes forms that are known from the deep Labrador Sea in the late Eocene to early Oligocene but have not been found in approximately coeval sediments in the southern Norwegian Sea. This group includes a number of species first described from deep-water sediments occurring in the Caribbean and in the Polish Carpathians. Several typically Atlantic abyssal forms such as Spiroplectammina cubensis, Trochamminoides spp., and Paratrochamminoides spp. have never been observed in the Norwegian Sea region. These forms are relatively common in the Oligocene Cipero Formation of Trinidad, for instance. Another example is the widely distributed deep-water species Glomospira charoides (Jones and Parker), which is common in the lower Oligocene of Hole 647A in the Labrador Sea. It disappeared from the Vøring Slope area during the Eocene. This species is occasionally observed in older (Paleocene to lower Eocene) strata in the Norwegian Sea and North Sea regions. Its absence north of the Greenland-Scotland Ridge (Holes 985A, 643A, and 913B) during the Oligocene again points to the faunal isolation of the deep Norwegian Sea Basin.

A second group of species is widely distributed along the Labrador margin and North Sea regions (Gradstein et al., 1994) as well as in the deep ODP holes. This group includes several index species that may be useful for correlation between the Tethys, Atlantic, and North Sea regions such as $R$. rotundidorsatum, $R$. amplectens, A. latus, $R$. elongatus, $S$. compressa, and $P$. gradsteini. These species apparently possessed a very wide bathymetric distribution during the Oligocene. We believe that the Greenland-Scotland Ridge apparently did not constitute a barrier to their migration into the Norwegian Sea and North Sea regions. It is likely that these species migrated into the Norwegian Basin with the incoming surface-water masses. Latest Eocene to Oligocene diatom assemblages from Holes 908 and 913 in the northern Norwegian Sea contain many low-latitude species, suggesting that warm waters were present (Scherer and Koç, 1996). This supports the premise that surface waters entered the Norwegian Sea from the Atlantic (or also via the North Sea), bringing temperate flo-

Table 2. Comparison of foraminiferal species occurring at Site 647 in the Labrador Sea (Kaminski et al., 1989) and at Sites 643 and 985 in the Norwegian-Greenland Sea (NGS) (Kaminski et al., 1990).

\begin{tabular}{|c|c|c|}
\hline $\begin{array}{c}\text { Deep Atlantic species } \\
\text { (Site 647) }\end{array}$ & $\begin{array}{l}\text { "Isobathyal" species } \\
\text { (Sites } 647 \text { and 985) }\end{array}$ & $\begin{array}{c}\text { NGS species } \\
\text { (Sites } 643 \text { and } 985 \text { ) }\end{array}$ \\
\hline $\begin{array}{l}\text { Spiroplectammina trinitatensis } \\
\text { Spiroplectammina cubensis } \\
\text { Paratrochamminoides } \text { spp. div. } \\
\text { Trochamminoides spp. div. } \\
\text { Karreriella chapapotensis } \\
\text { Glomospira charoides } \\
\text { Glomospira irregularis } \\
\text { Glomospira serpens } \\
\text { Subreophax spp. }\end{array}$ & $\begin{array}{l}\text { Budashevaella multicamerata } \\
\text { Reticulophragmium amplectens } \\
\text { Spirosigmoilinella compressa } \\
\text { Psamminopelta gradsteini } \\
\text { Cyclammina placenta } \\
\text { Haplophragmoides walteri } \\
\text { Reticulophragmium rotundidorsatum } \\
\text { Reophax elongatus } \\
\text { Reophax nodulosus } \\
\text { Glomospira gordialis } \\
\text { Ammodiscus latus } \\
\text { Ammolagena clavata } \\
\text { Ammosphaeroidina pseudopauciloculata }\end{array}$ & $\begin{array}{l}\text { Karreriella siegliei } \\
\text { Adercotryma agterbergi } \\
\text { Hyperammina rugosa } \\
\text { Conotrochamm voeringensis } \\
\text { Discammina sp. }\end{array}$ \\
\hline
\end{tabular}


ras and faunas as well as neritic benthic foraminifers (see also discussion by Thiede and Myhre, 1996). The species $R$. rotundidorsatum, $R$. amplectens, $S$. compressa, and A. pseudopauciloculata have also been reported from the Oligocene to lower Miocene of the BeaufortMackenzie Basin (Schröder-Adams and McNeil, 1994), indicating further faunal connections with the Arctic province, probably via the Fram Strait.

The third group of species constitutes "boreal" forms such as Karreriella siegliei, Adercotryma agterbergi, Conotrochammina voeringensis, and Annectina biedai. These species, so distinctive for the Oligocene of the North Sea and Norwegian Sea regions, have so far not been observed south of the Greenland-Scotland Ridge. These species are widely distributed in Paleogene sediments throughout the North Sea region (Charnock and Jones, 1990; Gradstein et al., 1994; Gradstein and Kaminski, 1997). Because their distribution in the Norwegian Sea is also isobathyal, their absence south of the ridge is more difficult to explain.

The absence of deep Atlantic species from the boreal seas (and the occurrence of some "endemic" species) is consistent with the theory that the Greenland-Scotland Ridge was a barrier to southern-source deep water and contributed to the isolation of Norwegian Sea deep water. During the Paleogene, marine connections across the Greenland-Scotland Ridge would have had shallower sill depths than at present, causing greater isolation of the deep-water mass than in the modern ocean. Instead, it is likely that the Oligocene deep waters of the Norwegian Sea had a greater affinity to Arctic deep waters because of the opening of the Fram Strait during Anomaly 13 (Berggren and Schnitker, 1983). At present, deep-ocean convection in the southern Norwegian sea occurs to depths of $3000 \mathrm{~m}$, resulting in a deep lysocline and well-oxygenated deep water (Jansen and Raymo, 1996). During the Oligocene, however, both sedimentological and faunal evidence point to a very different oceanographic setting. The lack of carbonate at the deep Norwegian Sea sites indicates a bottomwater mass that is both vertically stratified and corrosive. Although the presence of agglutinated foraminifers in the Oligocene sediments indicates that the bottom waters were probably never anoxic, the fact that calcareous benthic foraminifers have only been found at shallow sites on the Vöring Plateau suggests that convection, if present, involved only the thermocline waters.

In the absence of deep convection and open connections to the North Atlantic, it is reasonable to assume that the Norwegian Sea deep waters were poorly oxygenated during the Oligocene. The foraminiferal data at Site 985 and at other DSDP sites support this idea. The change from an early Oligocene coarsely agglutinated assemblage at the base of Hole 985A to a sparse assemblage with Psamminopelta gradsteini and pyritized diatom/radiolarian steinkerns in the upper Oligocene-Miocene sequence can be interpreted as reflecting increasingly dysaerobic conditions at the seafloor. In a study of Holocene DWAF from the California Borderlands basins, the change from a relatively diverse assemblage with coarsely agglutinated tubular forms to an assemblage displaying high dominance of small, thinwalled forms was observed as the bottom-water oxygen content falls below $0.5 \mathrm{~mL} / \mathrm{L}$ (Kaminski et al., 1995). The Oligocene-Miocene Psamminopelta gradsteini assemblage found at Site 985 and at other DSDP sites in the central Norwegian Sea (Verdenius and van Hinte, 1983) probably indicates a deep-sea environment that is strongly dysaerobic. By contrast, the deep-sea environment at Site 647 south of the Greenland-Scotland Ridge was well ventilated during the Oligocene, and assemblages contain diverse calcareous benthic foraminifers.

Our comparisons of Oligocene benthic foraminifers from various localities in the northern North Atlantic lead us to conclude that the Greenland-Scotland Ridge not only constituted a physical barrier (perhaps preventing some truly abyssal species from migrating into the boreal seas), but by isolating the Norwegian Sea deep water it caused extreme environmental conditions that excluded many of the isobathyal cosmopolitan species.

\section{ACKNOWLEDGMENTS}

W.E.N. Austin wishes to thank the British ODP Committee and the captain and crew of the JOIDES Resolution for the opportunity to participate on Leg 162 and to collect samples. He also acknowledges the support of the University of Durham Research Committee. M.A. Kaminski thanks S. Yakovleva for assistance with the additional sample preparation. We thank Timothy Herbert, John Murray, and Wolfgang Kuhnt for their constructive reviews of this paper. This is contribution 57 of the Cenozoic Deep-Water Agglutinated Foraminiferal Project.

\section{SYSTEMATICS}

The taxonomy of Norwegian Sea foraminifers used in this study follows the framework previously established by Kaminski et al. (1990). The following species represent modifications to the taxonomy that have been published subsequently.

\section{Psamminopelta gradsteini Kaminski and Geroch, 1997}

(Plate 1, fig. 4)

Psamminopelta sp. Kaminski et al., 1990, plate 4, figures 3, 4

Spirosigmoilinella compressa Matsunaga; Osterman and Spiegler, 1996, plate 1 , figure 17.

Psamminopelta gradsteini Kaminski and Geroch, 1997, plate 1, figures 1-9.

Remarks: This species, formerly lumped under Spirosigmoilinella compressa Matsunaga by various authors, differs in its small dimensions and wholly planispiral coiling. It is common in the deep parts of the Norwegian Sea.

Reticulophragmium rotundidorsatum (Hantken, 1875)

(Plate 1, figs. 5-7)

Haplophragmium rotundidorsatum Hantken, 1875, plate 1, figure 2.

Cyclammina (Reticulophragmium) rotundidorsata (von Hantken); Charnock and Jones, 1990, plate 7, figures 13-15; plate 19, figure 1.

Cyclammina rotundidorsata (Hantken); Gradstein et al., 1994, plate 6, figures 13, 14.

Reticulophragmium rotundidorsatus (von Hantken); Schröder-Adams and McNiel, 1994, plate 8, figures 5-7.

Remarks: Specimens from Hole 985A possess a long, thin basal aperture. and lack any additional supplementary openings in the apertural face. The species indeed conforms to the description of the genus Reticulophragmium as suggested by Schröder-Adams and McNiel (1994). However, the type species of the genus, the Miocene species Reticulophragmium venezuelanum, is not related to $R$. rotundidorsatum by phylogeny. The Paleogene species of Reticulophragmium are polyphyletic and are derived from different ancestors. Therefore, we only tentatively retain this species in Reticulophragmium pending revision of the whole group of Paleogene alveolar forms.

Karreriella siegliei (Gradstein and Kaminski, 1989) (Plate 1, fig. 8)

Dorothia siegliei Gradstein and Kaminski, 1989, text figure 3, plate 5, figures 1-5; plate 6, figures 1-5; Kaminski et al., 1990, pl. 8, figures 3, 4.

Karreriella siegliei (Gradstein and Kaminski); Charnock and Jones, 1990 plate 12 , figure 16 ; plate 25 , figure 7 .

Remarks: This is the nominate taxon of the $R$. bulimoides $-D$. siegliei Zone of Gradstein et al., 1994. Charnock and Jones transferred this species to the genus Karreriella because of its areal aperture.

Conotrochammina voeringensis Gradstein and Kaminski, 1997

Conotrochammina sp. Kaminski et al., 1990, plate 8, figures 1, 2; Osterman and Spiegler, 1996, plate 2, figures 33, 34.

Trochammina sp. 1 Charnock and Jones, 1990, plate 11, figures 4-6; plate 22, figure 5 . 
Conotrochammina voeringensis Gradstein and Kaminski, 1997, text figure 9, figure $10(1-3)$.

Remarks: Previous reports of this species are from the Paleocene of the North Sea (Charnock and Jones, 1990) and from the lower Eocene at Site 643 (Kaminski et al., 1990) and Site 913 (Osterman and Spiegler, 1996). This is the first report of this species from the Oligocene.

\section{REFERENCES}

Berggren, W.A., and Schnitker, D. 1983. Cenozoic marine environments in the North Atlantic and Norwegian-Greenland Sea. In Bott, M.H.P., Saxov, S., Talwani, M., Theide, J. (Eds.), Structure and Development of the Greenland-Scotland Ridge. NATO Conf. Ser. IV, New York (Plenum), 495-548.

Charnock, M.A., and Jones, R.W., 1990. Agglutinated foraminifera from the Paleogene of the North Sea. In Hemleben, C., Kaminski, M.A., Kuhnt, W., and Scott, D.B. (Eds.), Paleoecology, Biostratigraphy, Paleoceanography and Taxonomy of Agglutinated Foraminifera: Dordrecht (Kluwer Acad. Publ.), 139-244.

Geroch, S., and Nowak, W., 1984. Proposal of zonation for the late Tithonian-Eocene, based upon the aranaceous foraminifera from the Outer Carpathians, Poland. In Oertli, H.J. (Ed.) BENTHOS '83: 2nd Int. Symp. Benthic Foraminifera, Bull. Cent. Rech. Explor.-Prod. Elf-Aquitaine, 6:225-239.

Gradstein, F.M., and Bäckström, S., 1996. Cainozoic biostratigraphy and palaeobathymetry, northern North Sea and Haltenbanken. Norsk Geol. Tidsskrift, 76:3-32.

Gradstein, F.M., and Berggren, W.A., 1981. Flysch-type agglutinated foraminifera and the Maestrichtian to Paleogene history of the Labrador and North Seas. Mar. Micropaleontol., 6:211-268

Gradstein, F.M., and Kaminski, M.A.,1997. New species of Paleogene deepwater agglutinated foraminifera from the North Sea and Norwegian Sea. Annales Soc. Pol. Geol. 67:217-229.

, 1989. Taxonomy and biostratigraphy of new and emended species of Cenozoic deep-water agglutinated foraminifera from the Labrador and North Seas. Micropaleontology, 35:72-92.

Gradstein, F.M., Kaminski, M.A., and Berggren, W.A., 1988. Cenozoic foraminiferal biostratigraphy of the Central North Sea. Abh. Geol. Bundensanst (Austria), 41:97-108.

Gradstein, F.M., Kaminski, M.A., Berggren, W.A., Kristiansen, I.L., and D'Ioro, M.A., 1994. Cenozoic biostratigraphy of the North Sea and Labrador Shelf. Micropaleontology, 40 (Suppl.):1-152

Gradstein, F.M., Kristiansen, I.L., Loemo, L., and Kaminski, M.A., 1992. Cenozoic foraminiferal and dinocyst stratigraphy of the central North Sea. Micropaleontology 38:101-137.

Hantken, M., 1875. Die Fauna der Clavulina szaboi-Schichten; Theil I-Foraminiferen. Konigl.-Ungar. Geol. Anstalt, Mitt. Jahrb., Budapest, 4:1093.

Hulsbos, R.E., Kroon, D., Jansen, H.S.M., and van Hinte, J.E., 1989. Lower Eocene benthic foraminifera and paleoenvironment of the outer Vöring Plateau, Norwegian Sea (DSDP Site 338). Micropaleontology 35:256273

Jansen, E., and Raymo, M.E., 1996. Leg 162: new frontiers on past climates. In Jansen, E., Raymo, M.E., Blum, P., et al., Proc. ODP, Init. Repts. 162: College Station, TX (Ocean Drilling Program), 5-20.

Kaminski, M.A., Boersma, A., Tyszka, J., and Holbourn, A.E.L., 1995. Response of deep-water agglutinated foraminifera to dysoxic conditions in the California borderland basins. Spec. Publ._Grzybowski Found., 3: $131-140$.

Kaminski, M.A., and Geroch, S., 1997. Psamminopelta gradsteini n. sp., a new species of Paleogene deep-water agglutinated foraminifera from the northern North Atlantic and Polish Outer Carpathians. Spec. Publ.Grzybowski Found., 5:249-252.
Kaminski, M.A., Gradstein, F.M., and Berggren, W.A., 1989. Paleogene benthic foraminifer biostratigraphy and paleoecology at Site 647, southern Labrador Sea. In Srivastava, S.P., Arthur, M.A., Clement, B., et al., Proc. ODP, Sci. Results, 105: College Station, TX (Ocean Drilling Program), 705-730.

Kaminski, M.A., Gradstein, F.M., Goll, R.M., and Greig, D., 1990. Biostratigraphy and paleoecology of deep-water agglutinated foraminifera at ODP Site 643, Norwegian-Greenland Sea. In Hemleben, C., Kaminski, M.A., Kuhnt, W. \& Scott, D. (Eds.) Paleoecology, Biostratigraphy, Paleoceanography and Taxonomy of Agglutinated Foraminifera. NATO ASI Ser. C, 237:345-386

King, C., 1983. Cainozoic micropaleontological biostratigraphy of the North Sea. Inst. Geol. Sci. Rep., 82:1-40.

Myhre, A.M., and Thiede, J., 1995. North Atlantic-Arctic Gateways. In Myhre, A.M., Thiede, J., Firth, J.V., et al., Proc. ODP, Init. Repts. 151: College Station, TX (Ocean Drilling Program), 5-26.

Nagy, J., Kaminski, M.A., Johnsen, K., and Mitlehner, A., in press. Foraminiferal, palynomorph, and diatom biostratigraphy and paleoenvironments of the Paleogene Torsk Formation: a reference section for the western Barents Sea. Spec. Publ.-Grzybowski Found.

Osterman, L.E., and Spiegler, D., 1996. Agglutinated benthic foraminiferal biostratigraphy of Sites 909 and 913, northern North Atlantic. In Thiede, J, Myhre, A.M., Firth, J.V., Johnson, G.L., and Ruddiman, W.F. (Eds.), Proc. ODP, Sci. Results, 151: College Station, TX (Ocean Drilling Program), 169-185.

Schröder-Adams, C.J., and McNeil, D.H., 1994. Oligocene to Miocene agglutinated foraminifera in deltaic and deep-water facies of the Beaufort-MacKenzie Basin. Bull.-Geol. Surv. Can. 477.

Scherer, R.P., and Koç, N., 1996. Late Paleogene diatom biostratigraphy and paleoenvironments of the northern Norwegian-Greenland Sea. In Thiede, J, Myhre, A.M., Firth, J.V., Johnson, G.L., and Ruddiman, W.F. (Eds.), Proc. ODP, Sci. Results, 151: College Station, TX (Ocean Drilling Program), 75-99.

Shipboard Scientific Party, 1996. Site 985. In Jansen, E., Raymo, M.E., Blum, P., et al. Proc. ODP, Init. Repts., 162: College Station, TX (Ocean Drilling Program), 253-285.

Talwani, M., and Eldholm, O., 1977. Evolution of the Norwegian-Greenland Sea. Geol. Soc. Am. Bull. 88:969-999.

Talwani, M., Udintsev, G., et al., 1976. Init. Repts. DSDP, 38: Washington (U.S. Govt. Printing Office).

Thiede, J., and Eldholm, O., 1983. Speculations about the paleo-depth of the Greenland-Scotland Ridge during late Mesozoic and Cenozoic times. In Bott, M.H.P., Saxov, S., Talwani, M., and Theide, J. (Eds.), Structure and Development of the Greenland-Scotland Ridge. NATO Conf. Ser. IV: New York (Plenum), 8:445-456.

Thiede, J., and Myhre, A.M., 1996. The paleoceanographic history of the North Atlantic-Arctic gateways: synthesis of the Leg 151 drilling results. In Thiede, J, Myhre, A.M., Firth, J.V., Johnson, G.L., and Ruddiman, W.F. (Eds.), Proc. ODP, Sci. Results, 151: College Station, TX (Ocean Drilling Program), 645-658.

Verdenius, J.G., and van Hinte, J.E., 1983. Central Norwegian-Greenland Sea: Tertiary arenaceous foraminifera, biostratigraphy and environment. In Verdenius, J.G., van Hinte, J.E., Fortuin, A.R. (Eds.), Proc. 1st Workshop Arenaceous Foraminifera: Trondheim (Cont. Shelf Inst.), 173-223.

Worthington, L.V., 1976. On North Atlantic Circulation: (Johns Hopkins Univ. Press).

Date of initial receipt: 15 October 1997

Date of acceptance: 30 April 1998

Ms 162SR-006 

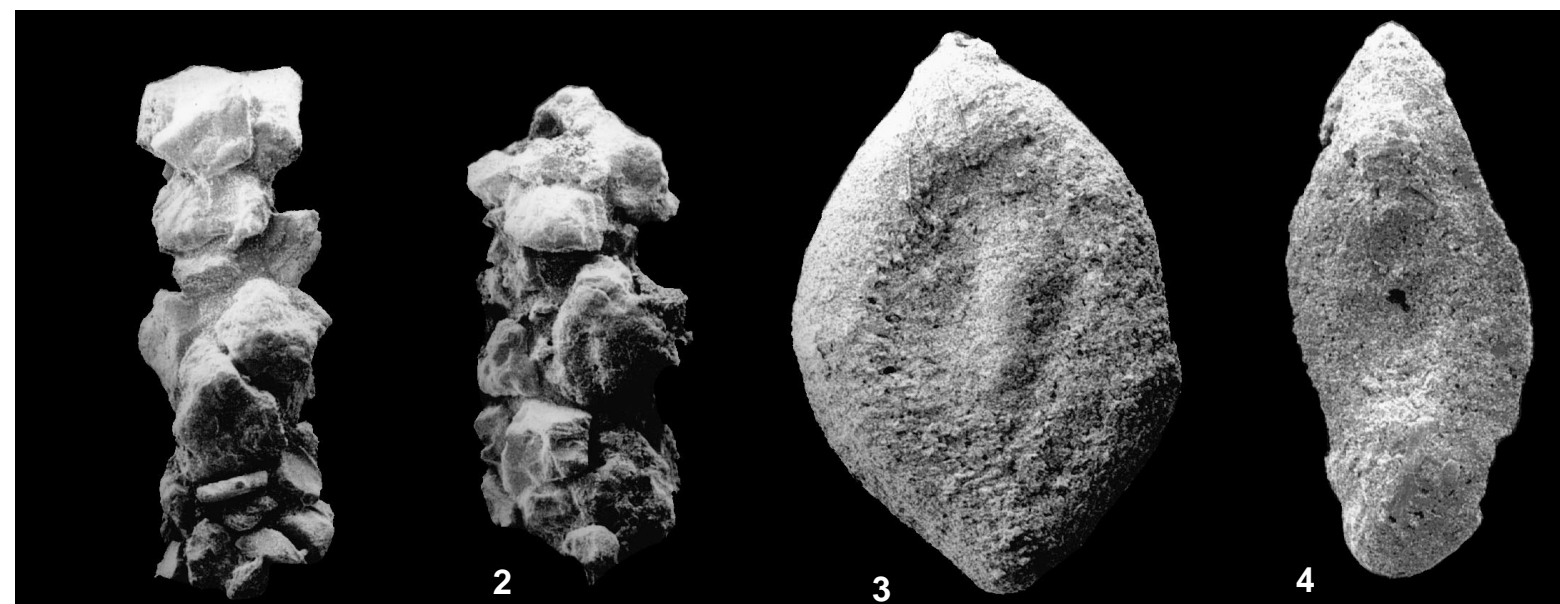

1
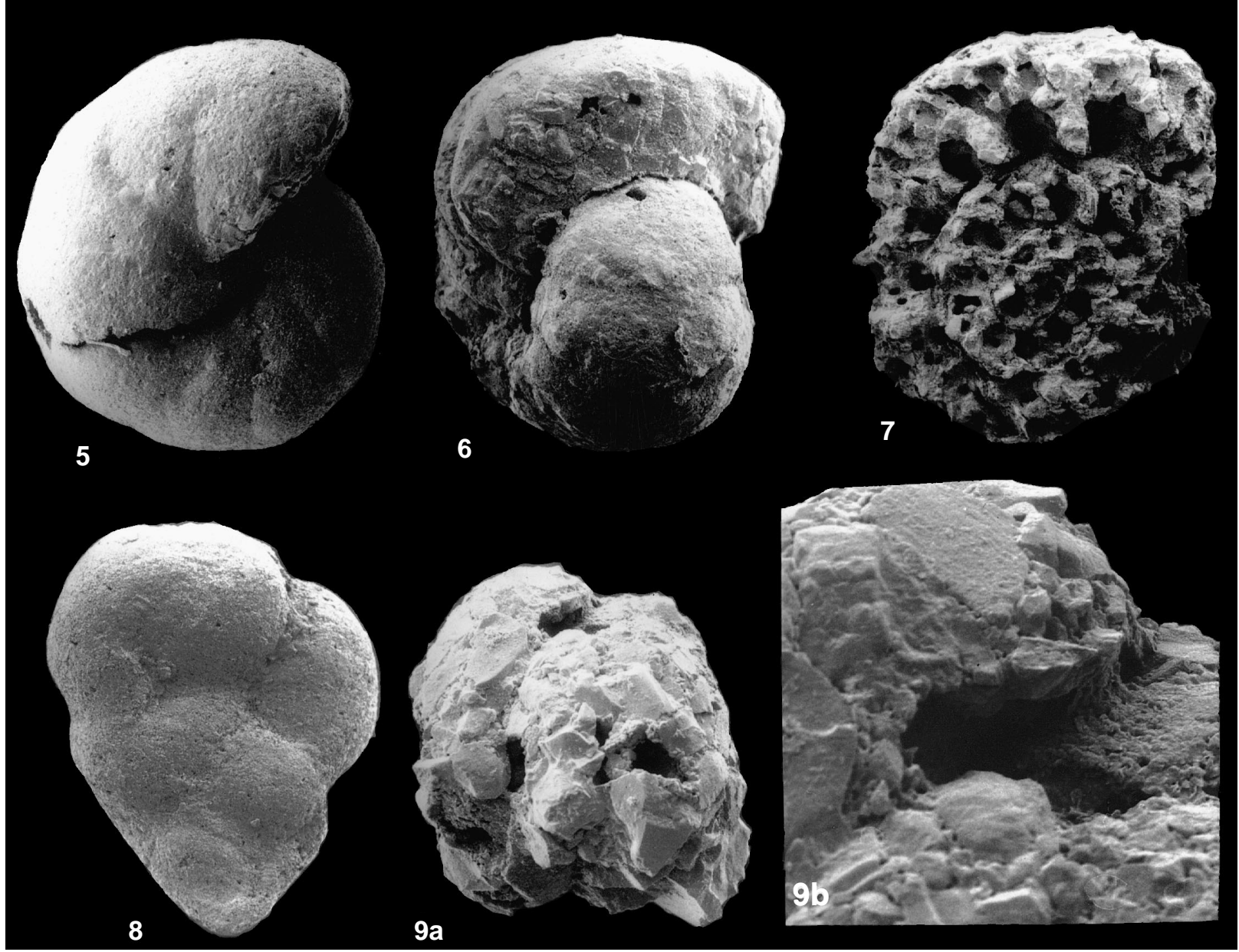

Plate 1. Stratigraphically important species of Hole 985A in the Oligocene. 1, 2. Hyperammina rugosa Verdenius and van Hinte: note extremely coarse agglutination. (1) 45×; (2) 32×. 3. Spirosigmoilinella compressa Matsunaga, 72×. 4. Psamminopelta gradsteini Kaminski and Geroch [= Psamminopelta sp. of Kaminski et al., 1990], 140×. 5-7. Reticulophragmium rotundidorsatum (Hantken). (5) Lateral view, 65×; (6) apertural view of an extraordinarily well-preserved specimen, 90×; (7) broken specimen showing simple alveoles, 75×. 8. Karreriella siegliei (Gradstein and Kaminski), 80×. 9a, 9b. Adercotryma agterbergi Gradstein and Kaminski. (9a) 200×; (9b) enlargement of aperture, which is umbilical in position with a small flap made of agglutinated particles, $700 \times$. 